\title{
Home alone? Creating accessible, meaningful online learning spaces to teach academic writing to doctoral students
}

\author{
Vera Leberecht
}

Keywords: teaching academic writing; doctoral writing; synchronous online teaching; Covid-19.

\section{The challenge}

The teaching of academic writing has seen disruptive changes since the Covid-19 pandemic began. Most prominently it signalled a need to turn to remote teaching at very short notice. Here, I share my experience as a self-employed academic writing teacher for doctoral students in Germany and its neighbouring countries.

In my writing workshops, rather than conveying knowledge or teaching techniques, I seek to support early career researchers as they explore what constitutes good academic writing in their research fields, expand their competencies, and develop their professional identities as members of their respective scientific communities (on writing as a social, embodied practice see: Kamler, 2008; Lee and Aitchison, 2009; Aitchison and Guerin, 2014; Kamler and Thomson, 2014). In my sessions I aim to create low-threshold, meaningful learning experiences that involve interacting with and learning from peers, working on real-life tasks, and being present as human beings with minds, emotions, and bodies (Immordino-Yang and Damasio, 2007; Immordino-Yang and Gotlieb, 2017). Another important aspect is the focus on participants' resources and on solutions rather than problems (Bamberger, 2015; Oades et al., 2017; Middendorf, 2019).

When the pandemic forced me to move my support online, I wanted to retain my successful hands-on, interactive, personal approach but this created three main challenges: how could I transfer a successful analog approach online while still taking seriously the participants' specific needs as academic professionals? How could I ensure the writing workshop stayed as accessible as possible and kept its sense of live presence/character? How could 
I support participants to reflect, interact, and connect as adult learners who do not just need and want to learn but also to contribute their own experiences and expertises (Knowles, Hilton III and Swanson, 2015)?

\section{The response}

To transfer as many qualities of a long-standing, well-evaluated teaching format to the online environment as possible, I took three major decisions: I wanted to deliver live (synchronous) sessions that felt real to the participants and that used simple technology.

I decided early to focus on synchronous training to engage participants in multiple ways (cognitive, social, visual, bodily-kinesthetic, etc. See: Gardner, 2011; Rapanta et al., 2020). The resulting shared live online space fostered a sense of togetherness, even though group members were not in the same physical room. I was visibly present in our virtual room during the whole workshop, even during small-group work. This availability and accessibility contributed to a focused atmosphere and was noted as a positive by participants. In addition, it enabled me to join small groups to answer questions and assist in technical/technological troubleshooting. Students reported that they appreciated my approach as it complemented the asynchronous, written forum discussions and feedback (e.g., on Moodle or Blackboard) offered by other colleagues.

I wanted my online teaching to have qualities which made it feel as real as its on-site counterpart. I reinforced this through the use of analogue objects and materials (flipchart, books, prompt cards) to complement digital whiteboards, slides, online resources, etc. I also encouraged participants to use long-hand writing (Mueller and Oppenheimer, 2014; Morehead, Dunlosky and Rawson 2019; Oppenheimer, 2019) for note-taking and other writing tasks.

To ensure that participants could focus on content and meaningful interaction (Turkle, 2017), I usually chose the simplest technical solution available. I did this in order to keep the training accessible for doctoral students, whose situations are traditionally precarious (Consortium for the National Report on Junior Scholars, 2021), and who were deprived of 
the institutional infrastructure they could formerly rely on (e.g., modern computers, broadband, etc.) when forced to work from home.

During the workshop, students spent considerable time on synchronous writing tasks (e.g, free writing, writing sprints, storytelling, and mind-mapping). During individual tasks, they could choose to stay visibly present to strengthen the community of writers, or to find another workplace. In small groups, they gave and received peer feedback on drafts produced on the same day, or in advance, and discussed individual challenges and useful writing strategies. Breaks could also be spent together in break-out rooms created for informal, relaxed interaction with peers.

Participants really appreciated the steps I took to retain my hands-on approach with its focus on connecting with fellow human beings ('I was underestimating the importance of dialogue and feedback, l'Il try to communicate more with my colleagues', 28 July 2020). They may have been at home, but they were not alone. The practical tasks I gave them were useful for creating an atmosphere of deeper thinking and playful experimentation in their writing ('I no longer fear writing. I now find writing playful', 8 September 2020; 'handwriting: this increased the output during the writing sessions a lot for me', 15 January 2021). Students reported feeling even more productive after the online sessions; attending a workshop virtually from the comfort zone of one's desk might make it easier to just sit down and write than when in an unfamiliar classroom.

\section{Recommendations}

When I developed more routine and confidence, after the initial turmoil of adapting to online teaching, I realised that effective teaching depends on many factors. As an educational professional, I wanted to create live, synchronous environments where young academics with diverse backgrounds could enter the professional conversation and connect with me, each other, and themselves - wherever possible.

I did not want to teach writing skills but to empower young people in the academy (PerisOrtiz and Lindahl, 2015; Rodríguez-Gómez and Ibarra-Sáiz, 2015). To reach this goal, I 
addressed multiple intelligences (Armstrong, 2009; Gardner, 2011), I used humour (Powell and Andresen, 1985) and a fair share of pragmatism (Silvia, 2018).

To sum it up, the real question is not whether we teach on-site or online, but what kind of teaching we provide (Ross, Bayne and Lamb, 2019; Bayne et al., 2020). Educators are constantly challenged to reflect on who they are, and who and what they care about. What do you want your students to take away from your class? Once we are aware of our own motivations and foundations, we can create the learning/teaching environments that best suit us and our learners - whether we meet in the physical or virtual world.

\section{References}

Aitchison, C. and Guerin, C. (eds.) (2014) Writing groups for doctoral education and beyond: innovations in practice and theory. London: Routledge.

Armstrong, T. (2009) Multiple intelligences in the classroom. $4^{\text {th }}$ edn. Alexandria: ASCD.

Bamberger, G. G. (2015) Lösungsorientierte Beratung. $5^{\text {th }}$ edn. Weinheim: Beltz.

Bayne, S., Evans, P., Ewins, R., Knox, J. and Lamb, J. (2020) The manifesto for teaching online. Cambridge: MIT Press.

Consortium for the National Report on Junior Scholars (2021) 2021 National Report on Junior Scholars. Statistical Data and Research Findings on Doctoral Students and Doctorate Holders in Germany. Overview of Key Results. Available at: https://www.buwin.de (Accessed: 10 June 2021).

Gardner, H. E. (2011) Frames of mind: the theory of multiple intelligences. 3rd edn. New York: Basic Books.

Immordino-Yang, M. H. and Damasio, A. (2007) 'We feel, therefore we learn: The relevance of affective and social neuroscience to education', Mind, brain, and education, 1(1), pp.3-10. https://doi.org/10.1111/j.1751-228x.2007.00004.x. 
Immordino-Yang, M. H. and Gotlieb, R. (2017) 'Embodied brains, social minds, cultural meaning: integrating neuroscientific and educational research on social-affective development', American Educational Research Journal, 54, pp.344S-367S. https://doi.org/10.1093/oxfordhb/9780199357376.013.9.

Kamler, B. (2008) 'Rethinking doctoral publication practices: writing from and beyond the thesis', Studies in Higher Education, 33(3), pp.283-294. https://doi.org/10.1080/03075070802049236.

Kamler, B. and Thomson, P. (2014) Helping doctoral students write: pedagogies for supervision. $2^{\text {nd }}$ edn. London: Routledge.

Knowles, M. S., Holton III, E. F. and Swanson, R. A. (2015) The adult learner: the definitive classic in adult education and human resource development. $8^{\text {th }}$ edn. London: Routledge.

Lee, A. and Aitchison, C. (2009) 'Writing for the doctorate and beyond', in Boud, D. and Lee, A. (eds.) Changing practices of doctoral education. London: Routledge, pp.8799.

Middendorf, J. (2019) Lösungsorientiertes coaching: kurzzeit-coaching für die praxis. $2^{\text {nd }}$ edn. Wiesbaden: Springer Fachmedien.

Morehead, K., Dunlosky, J. and Rawson, K. A. (2019) 'How much mightier is the pen than the keyboard for note-taking? A replication and extension of Mueller and Oppenheimer (2014)', Educational Psychology Review, 31(3), pp.753-780. https://doi.org/10.1007/s10648-019-09468-2.

Mueller, P. A. and Oppenheimer, D. M. (2014) 'The pen is mightier than the keyboard: advantages of longhand over laptop note taking', Psychological Science, 25(6), pp.1159-1168. https://doi.org/10.1177/0956797614524581. 
Oades, L. G., Steger, M., Delle Fave, A. and Passmore, J. (eds.) (2017) The Wiley Blackwell handbook of the psychology of positivity and strengths-based approaches at work. Chichester: John Wiley \& Sons.

Oppenheimer, D. (2019) 'The relative advantages and disadvantages of paper and digital media in education', Impact. Journal of the chartered college of teaching, 8. Available at: https://impact.chartered.college/article/the-relative-advantagesdisadvantages-paper-digital-media-education/ (Accessed: 10 June 2021).

Peris-Ortiz, M. and Lindahl, J. M. M. (eds.) (2015) Sustainable learning in higher education. Berlin: Springer.

Powell, J. P., and Andresen, L. W. (1985) 'Humour and teaching in higher education', Studies in Higher Education, 10(1), pp.79-90. https://doi.org/10.1080/03075078512331378726.

Rapanta, C., Botturi, L., Goodyear, P., Guàrdia, L. and Koole, M. (2020) 'Online university teaching during and after the Covid-19 crisis: refocusing teacher presence and learning activity', Postdigit Sci Educ, 2, pp.923-945. https://doi.org/10.1007/s42438$\underline{020-00155-y .}$

Rodríguez-Gómez, G. and Ibarra-Sáiz, M. S. (2015) 'Assessment as learning and empowerment: Towards sustainable learning in higher education', in Peris-Ortiz, M. and Lindahl, J. M. M. (eds.) Sustainable learning in higher education. Berlin: Springer, pp.1-20.

Ross, J., Bayne, S. and Lamb, J. (2019) 'Critical approaches to valuing digital education: learning with and from the Manifesto for Teaching Online', Digital Culture and Education, 11(1), pp.22-35. Available at: https://static1.squarespace.com/static/5cf15af7a259990001706378/t/5dea73f08c35 4b64fb152aae/1575646198702/Cover-merged.pdf (Accessed 10 June 2021).

Silvia, P. J. (2018) How to write a lot: a practical guide to productive academic writing. $2^{\text {nd }}$ edn. Washington: American Psychological Association. 
Turkle, S. (2017) Alone together: why we expect more from technology and less from each other. New York: Basic Books.

\section{Author details}

Vera Leberecht studied Linguistics, Intercultural Communication and Theology in Germany and Finland. She worked at Maastricht University Language Centre for several years, first as a teacher for academic writing, then as a head of department of the English Section. In 2008, she left the university to start her own training and consulting business. She is passionate about empowering professionals to communicate with reason and resonance, in academia and beyond. 